\title{
Does Work-Life Balance Predict the Nurses' Organizational Commitment?
}

\author{
${ }^{1}$ Department of Psychology, Medical Faculty, Universitas Hasanuddin, Indonesia \\ ${ }^{2}$ Department of Psychology, Medical Faculty, Universitas Hasanuddin, Indonesia \\ ${ }^{3}$ Department of Psychology, Medical Faculty, Universitas Hasanuddin, Indonesia \\ ${ }^{4}$ Department of Psychology, Medical Faculty, Universitas Hasanuddin, Indonesia \\ *Corresponding author.Email: rezkyariany@unhas.ac.id
}

Rezky Ariany $\operatorname{Aras}^{1}{ }^{*}$ Sri Wahyuni ${ }^{2}$, Yuli Wardani ${ }^{3}$, Syurawasti Muhiddin $^{4}$

\begin{abstract}
Nurses play a significant role among all health workers in the hospital because they directly interact with patients; thus, their organizational commitment is essential for ensuring their professionality in delivering service. This study aimed to examine the contribution of work-life balance of nurses' organizational commitment at Makassar Hospital. A total of 116 nurses at Makassar Hospital filled out two scales, Work-Life Balance Scales and Organizational Commitment Scale. The data were analyzed using simple linear regression. This result showed that work-life balanced predict the organizational commitment of the nurses. The higher the work-life balance, the higher the organizational commitment. This study implies the importance of understanding and increasing worklife balance as a part of well-being to improve organizational commitment and work performance.
\end{abstract}

Keywords: Work-life balance, Organizational Commitment, Nurses,

\section{INTRODUCTION}

The nurses are the significant employees among all health workers in the hospital, which play an essential role in providing services in hospitals because they are directly involved with patients for 24 hours [1]. They are a determining factor for service quality and hospital image. Therefore, nurses have to be professional in carrying out their duties by cultivating a sense of concern and empathy for patients.

Nevertheless, nurses sometimes do not show professionalism in their work which can be related to commitment and various other factors. The low commitment of nurses might cause a lot of harm to the organization. For example, increasing organizational expenses and the interruption of patient care as well as harming the job satisfaction and safety of nurses and other health workers [2]. The low commitment also negatively impacts customer satisfaction and loyalty, affecting their perception of service quality [3]. In addition, it can also increase the incidence of workplace accidents, wound infections, increased mortality, and turnover rates [3],[4].
Since nurses play important roles, it is crucial to give attention to their commitment [5]. Every hospital as an organization should manage and educate nurses; thus, they have comfort work and provide a reciprocal state of harmony between acceptance and sacrification of the nurses.

\subsection{Organizational Commitment}

Organizational commitment is a psychological construct characterized by the members' relationships with their organization, which further have implications for individual decisions to continue membership [6]. According to several studies, organizational commitment is an attitude possessed by individuals towards the organization where they perceived their involvement in the success and progress of the organization, as well as loyalty to stay in the organization [7],[8].

There are three components of commitment organization: identification, engagement, and loyalty [9]. Identification is manifested in trust and acceptance of the overall values and goals of the organization. For 
example, individuals' agreement to the values and rules that existed in the organization and their pride in being part of the organization. Engagement is reflected in the willingness of employees to perform well in the interests of the organization according to their duties and responsibilities within the organization. For example, some members carry out orders or tasks to the best of their ability. Meanwhile, the loyalty aspect can be seen from a strong desire to maintain membership. Loyalty to the organization evaluates commitment and an emotional attachment to the organization. If members have a high commitment to the organization, then the member has loyalty and a sense of belonging to the organization [9].

Several factors are affecting organizational commitment. Those are personal characteristics (e.g., age, tenure, motives, and gender); job characteristics (e.g., role clarity and alignment, feedback, and job challenges); structural characteristics (e.g., the degree of formalization and decentralization); work experiences, humanity values; comprehensive twoway communication; organizational vision and mission; a sense of community and familiarity; and basic recruitment values [9],[10].

\subsection{Work-Life Balance}

Work-life balance is a theory that explains how individuals regulate work, family environments, and stress two to achieve balance [11]. It is essential to underline that work-life balance does not mean allocating the same time in jobs and other roles. However, work-life balance is defined as satisfaction with various roles' involvement [12]. In sum, work-life balance is defined as a perceived state of balance due to the low conflict between personal/family life and work demands; thus, the different roles can play in harmony [11], [13], [14].

The work-life balance consists of four dimensions: Work Interference with Personal Life (WIPL), Personal Life Interference with Work (PLIW), Personal Life Enhancement of Work (PLEW), and Work Enhancement of Personal Life (WEPL). The first and second dimensions refer to the extent to which work and personal life can interfere, while the third and fourth dimensions refer to the degree to which both can support each other [15]. Another literature describes three dimensions of work-life balance: time balance, involvement balance, and satisfaction balance [16].
The work-life balance has had a positive impact on individuals and organizations. For individuals, it increased job satisfaction, job security, control over the work-life environment, and physical and mental health (e.g., reducing stress level). The work-life balance decreased cost for organizations, enhanced organizational image, retention, productivity, and employee performance [12].

\subsection{The Current Study}

Lockett reinforced the importance of implementing a work-life balance in an organization, which states that an organization that applies a worklife balance to its members will increase organizational commitment. Several studies also show that the work-life balance contributes positively to organizational commitment [17]-[22]. Thus, this study aimed to examine the contribution of work-life balance to nurses' organizational commitment at Makassar Hospital. According to preliminary interviews with two nurses, we found several work stress symptoms that influenced their commitment. For example, they said the difficulty in gathering with family when having duties. They used to feel nervous because it was difficult to determine priorities. In addition, even during religious celebrations, they find it difficult to gather with their families. This situation sometimes brought them to question their loyalty. We hypothesized that the work-life balance positively contributes to nurses' organizational commitment.

\section{METHOD}

This quantitative study collected data from 116 nurses $(52 \%$ of 225 total numbers of nurses at $\mathrm{X}$ hospital, Makassar). The participants filled out two scales during the data collection: work-life balance and organizational commitment scales. The workbalance scale is a Likert scale ( 1 - 5; with $1=$ strongly disagree and $5=$ strongly agree) adapted from Fisher, Bulger \& Smith in 2009 [15], consisting of the four dimensions previously mentioned and 17 items (6 favorable items and 11 unfavorable items). For example, 'because of my work, my mood is getting better when I am at home', 'I often ignore my personal need due to my job demands'. The organizational commitment scale is also a Likert scale modified from Suherlan [23] based on 1979 Mowdays' proposed dimension of organizational commitment, comprising 24 items (every 12 items favorable and unfavorable). The examples of items are 'I support and do what be a hospital decision' and 'I don't want to help with 
another part if not rewarded'. The validity and reliability of the measures were satisfied. Confirmatory Factor Analysis was conducted and revealed the model fit for two measurements. The Cronbach Alpha reliability is also relatively high: 0.895 for the work-life balance scale and 0.899 for the organizational commitment scale. We analyzed the data with linear regression analysis using SPPS 20 for windows.

\section{RESULT}

\subsection{Participants Demographic}

Table 1 shows the summary of the participants' demographics.

Table 1. Participants' demographics.

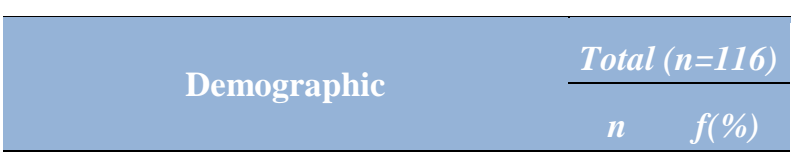

\begin{tabular}{lrr} 
1. Gender & & \\
\hline Male & 103 & 88.8 \\
\hline Female & 13 & 11.2 \\
\hline
\end{tabular}

2. Age

\begin{tabular}{lrr}
\hline $21-25$ y.o & 9 & 7.8 \\
\hline $26-30$ y.o & 60 & 51.7 \\
\hline $31-40$ y.o & 20 & 17.2 \\
\hline $36-40$ y.o & 17 & 14.7 \\
\hline$>40$ y.o & 10 & 8.6 \\
\hline
\end{tabular}

3. Length of work

\begin{tabular}{lrr}
$\leq 5$ years & 45 & 38.8 \\
\hline $6-10$ years & 41 & 35.3 \\
\hline $11-15$ years & 11 & 9.5 \\
\hline $16-20$ years & 8 & 6.9 \\
\hline$>20$ years & 11 & 9.5 \\
\hline
\end{tabular}

\section{Education}

\begin{tabular}{lll}
\hline S1 (Bachelor) & 54 & 46.6 \\
\hline D3 (Diploma) & 62 & 53.4 \\
\hline
\end{tabular}

\section{Marital Status}

Married

$66 \quad 56.9$

Single

$50 \quad 43.1$

\section{Number of children}

\begin{tabular}{lll}
\hline No children & 71 & 61.2 \\
\hline $1-2$ & 32 & 27.6 \\
\hline$>2$ & 13 & 11.2 \\
\hline
\end{tabular}

\subsection{Descriptive Statistic}

Table 2 elicits the descriptive statistic and the correlations between two variables.

Table 2. Descriptive statistics and intercorrelation

\begin{tabular}{lllllll}
\hline \multicolumn{1}{c}{ Variable } & Min & Max & M & SD & 1 \\
\hline $\begin{array}{l}\text { 1.Work-Life } \\
\text { Balance (WLB) }\end{array}$ & 28 & 73 & 55.16 & 11.487 & - \\
\hline $\begin{array}{l}\text { 2.Organization } \\
\text { al Commitment }\end{array}$ & 40 & 107 & 73.59 & 14.692 & $0.588^{* *}$ \\
(OC) & & & & & & \\
\end{tabular}

The positive correlation described that the higher the work-life balance, the higher the organizational commitment of the nurse.

\subsection{Hypothesis testing}

The results of regression analysis showed that work-life balance predicted the nurses' organizational commitment at Makassar Hospital, $R=0.588, R^{2}=$ $0.346, F(1,116)=60.271 p=<0.001$.

\section{DISCUSSION}

This study's objection is to know work-life balance's contribution to nurses' organizational commitment at Makassar Hospital. The result showed that perceived work-life balance contributed to the nurses' organizational commitment by $34,6 \%$. Another $65.4 \%$ is influenced by other factors that are not investigated in this study. Therefore the alternative hypothesis of the study was accepted.

Organizational commitment is the relative strength of the individual in identifying his involvement with a part of the organization. It is reflected through acceptance of the values and goals, readiness, willingness to try hard, and the desire to maintain membership in the organization [9]. Meanwhile, work- 
life balance is defined as a state when individuals can balance their personal life with their work-life [15].

This study supported previous research showing that work-life balance can predict organizational commitment in several organizational and industrial contexts. Rane \& Wahyuni found a contribution between work-life balance and organizational commitment of insurance company employees [24]. Sasmitha found that the work-life balance indicator significantly contributed to the organizational commitment of lecturers at universities [25]. Similarly, Pradhan et al. also found a positive influence of work-life balance and organizational commitment to executive employees of the manufacturing industry [21]. In addition, a study by Allen showed that work-life balance is related to employees' level of organizational commitment, which further determines perceptions in supporting the organization [26].

Several previous studies are also in line with this study result in the hospital context. Rizkiana found that work-life balance can directly affect the organizational commitment of Public Hospital employees [27]. Azeem \& Altalhi's research on hospital employees in Saudi Arabia also showed a positive and significant relationship between work-life balance and employee commitment [28]. Another study conducted by Azeem \& Akhtar on Healthcare Employees in the Northern State of Pradesh in India revealed that work-life balance and job satisfaction are essential to develop and increase organizational commitment among healthcare workers [17].

The work-life balance also may indirectly affect the organizational commitment through a perceived well-being-related state. A study found that work-life balance contributes to employee engagement, such as job satisfaction and organizational commitment, ultimately contributing to higher productivity and lower organizational turnover. Individuals who have a good work-life balance will feel happiness in carrying out their roles [29]. These feelings finally encourage individuals to achieve goals and build commitment to their organizations [30]. This further implies that improving organizational commitment is not only promoting the work-life balance but also in other wellbeing states.

Since work-life balance is related to the balance between private and works life, women are sometimes associated with a lower work-life balance due to their double roles as working mothers. A study revealed a strong relationship and significant influence between work-life balance and organizational commitment for working women [19]. The majority gender of the participants is women; thus, this study can support the relationship between women's work-life balance and organizational commitment. However, most women participants do not have children, meaning they do not play a mother role.

The relationship between work-life balance and organizational commitment can also be explained using the Self-Determination Theory (SDT) [31]. The work-life balance can be considered as a basic psychological need for nurses. Deci \& Ryan (1987) explain three forms of individual basic psychological needs: autonomy, competence, and relatedness. One of the most basic needs is the need for autonomy, referring to the extent to which individuals experience the ability to make their own decisions and act without the control of others, as well as the extent to which people have the impression that these decisions are following the norms and values of the individual [32].

Autonomy is one of the important things to achieve work-life balance. With higher autonomy, nurses can evaluate themselves that they have made the right decisions in their lives; they can carry out their job roles as officers who serve the community and carry out functions outside of their work. Achieving a feeling of balance in performing their role makes nurses feel happy, satisfied, and responsible for their work so that it encourages individuals to be more committed to their organizations. Breaugh stated when the psychological basis is fulfilled at work, it causes a sense of full responsibility and is more committed to the job [33].

This study has several limitations that can be overcome in subsequent similar studies. In terms of the analysis, this study did not involve controls in submitting the hypothesis. Subsequent research can consider several demographic variables as controls to increase confidence regarding the contribution of independent variables. Regarding the procedure, the process of filling out the scale was not entirely under the researcher's supervision because most of the scales were given to the head nurse which was then distributed to the respondents. This procedure allows respondents to provide answers that are not following the actual situation. Furthermore, related to the number of samples, the coverage of nurses can be expanded, not only in one hospital. Considering the proportion of sex and age is also important for future research. These conditions can increase confidence in the generalization process of the findings. In general, 
further research can be designed to examine which aspects of work-life balance predict organizational commitment more.

\section{CONCLUSION}

This study shows that work-life balance can predict nurses' organizational commitment at the Makassar Hospital. This study also implies that work-life balance is closely related to well-being and workers' mental health issues. This idea further brings practical implications that one of the efforts to support organizational commitment is to create a situation that can keep a work-life balance because this will generate well-being conditions. Hospital policymakers may consider conducting training to increase nurses' awareness of work-life balance and the skills to achieve it.

\section{AUTHORS' CONTRIBUTIONS}

The first, the second and the third author contributed in research plan, data collection and analysis. The fourth author wrote the final manuscript.

\section{REFERENCES}

[1] Suroso J. Penataan sistem jenjang karir berdasar kompetensi untuk meningkatkan kepuasan kerja dan kinerja perawat di rumah sakit. Eksplanasi. 2012 Feb 9;6(2).

[2] Siew PL, Chitpakdee B, Chontawan R. Factors predicting organizational commitment among nurses in state hospitals, Malaysia. IIUM Medical Journal Malaysia. 2011 Dec 1;10(2).

[3] Baumann A, Conseil international des infirmières, Fondation Internationale Florence Nightingale, Centre international des ressources humaines pour les soins infirmiers. The impact of turnover and the benefit of stability in the nursing workforce. International Council of Nurses; 2010.

[4] $\mathrm{Fu} \mathrm{JR,} \mathrm{Chen} \mathrm{JH.} \mathrm{Career} \mathrm{commitment} \mathrm{of}$ information technology professionals: The investment model perspective. Information \& Management. 2015 Jul 1;52(5):537-49.

[5] Purwanto SK. Mengembangkan Hubungan Industrial yang Sehat. Bisnis Indonesia. 2006 Apr;7.

[6] Meyer JP, Allen NJ, Smith CA. Commitment to organizations and occupations: Extension and test of a three-component conceptualization.
Journal of applied psychology. 1993 Aug;78(4):538.

[7] Luthans F. Organizational Behavior: An Evidence-Based Approach Published By Mcgraw-Hill/Irwin, A Business Unit Of The Mcgraw-Hill Companies, Inc., 1221 Avenue Of The Americas, New York, Ny, 10020.

[8] Mowday RT, Steers RM, Porter LW. The measurement of organizational commitment. Journal of vocational behavior. 1979 Apr $1 ; 14(2): 224-47$.

[9] Mowday RT, Porter LW, Steers RM. Employee - organization linkages: The psychology of commitment, absenteeism, and turnover. Academic press; 2013 Sep 17.

[10] Dessler G. Managing organizations in an era of change. Dryden Press; 1995.

[11] Clark SC. Work/family border theory: A new theory of work/family balance. Human relations. 2000 Jun;53(6):747-70.

[12] Lazar I, Osoian C, Ratiu P. The role of work-life balance practices in order to improve organizational performance. 2010

[13] Clarke MC, Koch LC, Hill EJ. The work-family interface: differentiating balance and fit. Family and consumer sciences research journal. 2004 Dec;33(2):121-40.

[14] Rincy VM, Panchanatham N. Development of a psychometric instrument to measure work life balance. Continental Journal of Social Sciences. 2010 Jan 1;3:50.

[15] Fisher GG, Bulger CA, Smith CS. Beyond work and family: a measure of work/nonwork interference and enhancement. Journal of occupational health psychology. 2009 Oct;14(4):441.

[16] Greenhaus JH, Collins KM, Shaw JD. The relation between work-family balance and quality of life. Journal of vocational behavior. 2003 Dec 1;63(3):510-31.

[17] Azeem SM, Akhtar N. The influence of work life balance and job satisfaction on organizational commitment of healthcare employees. International Journal of Human Resource Studies. 2014 Apr 1;4(2):18.

[18] Veloso EF, da Silva RC, Dutra JS, Fischer AL, Trevisan LN. Talent retention strategies in different organizational contexts and intention of talents to remain in the company. Journal on 
Innovation and Sustainability RISUS. 2014 Jan 20;5(1):49-61.

[19] Nwagbara U, Akanji B. The impact of work-life balance on the commitment and motivation of Nigerian women employees. 2012.

[20] Parkers LP, Langford PH. Work-life balance or work-life alignment. Journal of Management \& Organization. 2008 Jul;14(3):267-84.

[21] Pradhan RK, Jena LK, Kumari IG. Effect of work-life balance on organizational citizenship behaviour: Role of organizational commitment. Global Business Review. 2016 Jun;17(3_suppl):15S-29S.

[22] da Silva RC, Dutra JS, Veloso EF, Fischer AL, Trevisan LN. Generational perceptions and their influences on organizational commitment. Management Research: The Journal of the Iberoamerican Academy of Management. 2015 Jun 15.

[23] Suherlan, A. Q. Hubungan Locus of Control dengan Komitmen Organisasi (Studi Pada Karyawan Perusahaan Multifinance PT. X Cabang Makassar). Makassar: Skripsi. Program Studi Psikologi Universitas Hasanuddin. 2017.

[24] Rene R, Wahyuni S. Pengaruh work-life balance terhadap komitmen organisasi, kepuasan kerja, dan motivasi kerja terhadap kinerja individu pada karyawan perusahaan asuransi di jakarta. Jurnal Manajemen Dan Bisnis Sriwijaya. 2018 Oct 7;16(1):53-63.

[25] Mishra S, Mohanty JK. The predictors of employee engagement: A study in a ferro alloys company of India. Global Business Review. 2016 Dec;17(6):1441-53.

[26] Allen NJ, Meyer JP. The measurement and antecedents of affective, continuance and normative commitment to the organization. Journal of occupational psychology. 1990 Mar;63(1):1-8.

[27] RIZKIANA D. Hubungan antara Work Life Balance dengan Komitmen Organisasi (Doctoral dissertation, Universitas Gadjah Mada). 2015.

[28] Azeem SM, Altalhi H. Role of perceived worklife balance and job satisfaction in developing organizational commitment among hospital employees in Saudi Arabia. International Journal of Academic Research in Business and Social Sciences. 2015 Dec;5(12):185-97.

[29] Parkers LP, Langford PH. Work-life balance or work-life alignment. Journal of Management \& Organization. 2008 Jul;14(3):267-84.
[30] Wagner JA, Hollenbeck JR. Organizational behavior. New York: Routledge. 2010.

[31] Deci EL, Ryan RM. The support of autonomy and the control of behavior. Journal of personality and social psychology. 1987 Dec;53(6):1024.

[32] Moller AC, Deci EL, Ryan RM. Choice and egodepletion: The moderating role of autonomy. Personality and social psychology bulletin. 2006 Aug;32(8):1024-36.

[33] Gagné M, Deci EL. Self-determination theory and work motivation. Journal of Organizational behavior. 2005 Jun;26(4):331-62. 